\title{
HUBUNGAN PENGETAHUAN LINGKUNGAN HIDUP DENGAN KEMAMPUAN PEMECAHAN MASALAH PENCEMARAN LINGKUNGAN PADA SISWA SMAN 6 TANGERANG
}

\author{
Diana Vivanti Sigit, Ernawati, Mariatul Qibtiah \\ Pendidikan Biologi, Fakultas, MIPA, Universitas Negeri Jakarta \\ email: dianavivanti@yahoo.com
}

\begin{abstract}
Environment knowledge is collection of facts, information and the principles of concerning something that there are around living things. Environment knowledge related to problem solving skills that is the process of applying of knowledge which has previously obtained into a new situation unknown. The purpose of this study is to find correlation environment knowledge with the problem solving skills about environmental pollution. The study was conducted in April-May 2016 at SMAN 6 Tangerang. The research methodology was survey with the study correlation. Samples were taken at random with Simple Random Sampling technique, as many as 127 students of science tenth grade. Prerequisite test showed data normal and homogeny. Regression model $\hat{Y}=24,24+1,10 X$ that significance and had a linier correlation. Correlation values obtained 0,42 which was sufficient criteria. Coefficient of determination test showed that $17,62 \%$ of environmental knowledge contribute to the problem solving about environmental pollution. The conclution of this study there was positive correlation between environmental knowledge and problem solving environmental pollution.
\end{abstract}

Keywords: Environmental, Knowledge, Problem solving.

\section{PENDAHULUAN}

Manusia secara ekologis adalah bagian dari lingkungan hidup. Lingkungan hidup tidak semata-mata hanya dipandang sebagai sumberdaya yang harus dieksploitasi. Akan tetapi sebagai tempat hidup yang mensyaratkan adanya keserasian antara manusia dengan lingkungan hidupnya. Menurut Sastrawijaya (2009), antara manusia dan lingkungan hidupnya terdapat hubungan timbal balik. Manusia mempengaruhi lingkungan hidupnya, dan sebaliknya manusia dipengaruhi oleh lingkungan hidupnya.

Sekarang ini pertumbuhan manusia semakin meningkat. Hal ini juga meningkatkan kebutuhan untuk sandang, pangan, papan, dan lain sebagainya. Kebutuhan ini diperoleh melalui eksploitasi sumber daya alam, sehingga proses pemenuhan tersebut secara langsung maupun tidak langsung menimbulkan masalah pencemaran lingkungan.

Kota Tangerang merupakan salah satu kota terbesar di provinsi Banten. Kota yang dikenal dengan kota seribu industri dan sebagai pusat manufaktur di pulau Jawa dengan banyak perusahaan-perusahaan internasional tidak lepas dari masalah lingkungan. Permasalahan tersebut menimbulkan adanya pencemaran limbah industri, rumah tangga, kesehatan, dan lain sebagainya (Badan Lingkungan Hidup Kota Tangerang, 2015). Sebab itulah, maka dibutuhkan upaya untuk menanggulangi pencemaran lingkungan yang terjadi.

Salah satu upaya untuk menanggulangi pencemaran lingkungan yaitu perlu ditanamkan pengetahuan lingkungan kepada masyarakat khususnya siswa. Siswa 
merupakan komponen pendidikan yang diharapkan dapat memberi perubahan lebih baik terhadap lingkungan. Oleh karena itu, siswa harus dididik untuk mengetahui, menyadari dan meyakini akan adanya keterbatasan-keterbatasan alam yang memberikan kehidupan di bumi ini.

Adanya pengetahuan yang diperoleh dapat menjadikan siswa berwawasan lingkungan hidup, sehingga terciptanya pemecahan-pemecahan masalah yang solutif dalam pencemaran lingkungan. Maka, dilakukanlah penelitian ini untuk mengetahui hubungan pengetahuan lingkungan hidup dengan kemampuan pemecahan masalah pencemaran lingkungan.

\section{METODE}

Penelitian ini menggunakan metode survei melalui studi korelasional. Adapun yang menjadi variabel bebas adalah pengetahuan lingkungan hidup (X) dan variabel terikatnya adalah kemampuan pemecahan masalah pencemaran lingkungan (Y). Penelitian ini dilakukan di SMAN 6 Tangerang pada bulan April sampai Mei 2016.

Populasi target adalah seluruh siswa di SMAN 6 Kota Tangerang. Populasi terjangkau dalam penelitian ini siswa kelas X MIA SMAN 6 Tangerang pada semester genap Tahun Ajaran 2016/2017 sebanyak lima kelas dengan jumlah seluruh siswa yaitu 200 siswa. Menurut Sugiyono (2014), pada tabel penentuan jumlah sampel yang dikembangkan oleh Isaac dan Michael dengan taraf kesalahan 5\%, maka sampel penelitian ini diambil secara simple random sampling sebanyak 127 siswa. Empat kelas digunakan sebagai penelitian dengan jumlah setiap kelas sebanyak 31-32 siswa. Sedangkan satu kelas sisa dengan jumlah 40 siswa dilakukan uji validitas dan reliabilitas.

\section{HASIL DAN PEMBAHASAN}

Berdasarkan data yang diperoleh dari 127 responden, nilai pengetahuan lingkungan hidup tertinggi yaitu 94 dan nilai terendah yaitu 55. Berdasarkan perhitungan, diperoleh rata-rata nilai pengetahuan lingkungan hidup sebesar 76, simpangan baku sebesar 9,07, variansi sebesar 82,32, dan rentang sebesar 39. Nilai tertinggi berada pada rentang nilai 7378 yaitu sebanyak 40 responden $(31,50 \%)$. Nilai terendah berada pada rentang nilai 91-96 yaitu sebanyak 5 responden $(3,94 \%)$. Kriteria pengetahuan lingkungan hidup sangat tinggi diperoleh 42 responden dengan persentase $37 \%$, sementara kriteria pengetahuan cukup tinggi diperoleh sebanyak 6 responden dengan persentase 4\%. Jika dilihat dari tiga dimensi pengetahuan yang digunakan sebagai indikator, dimensi faktual memiliki persentase tertinggi yaitu $36,52 \%$, sementara dimensi prosedural memiliki persentase terendah yaitu sebesar $26,68 \%$.

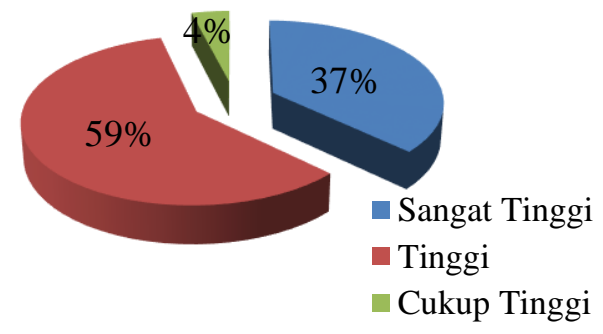

Gambar 1. Diagram lingkaran persentase jumlah siswa berdasarkan kategori penilaian pengetahuan lingkungan hidup 


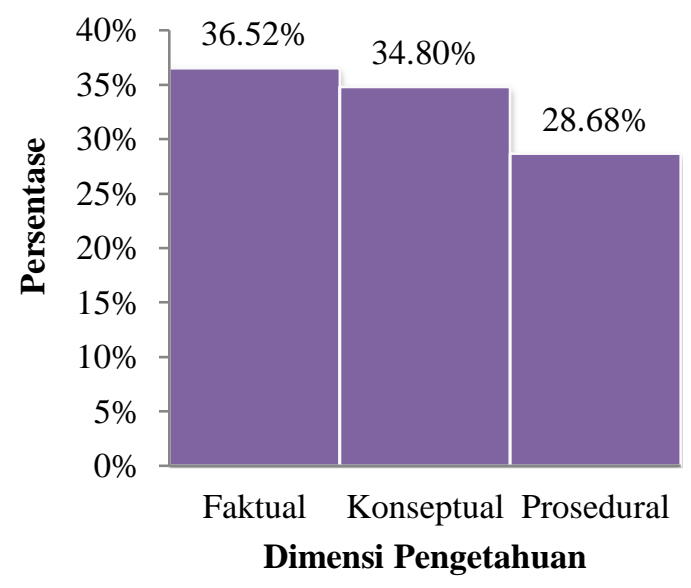

Gambar 2. Diagram batang persentase nilai rata-rata yang dicapai siswa pada dimensi Pengetahuan

Hasil yang diperoleh dari 127 responden, nilai kemampuan pemecahan masalah pencemaran lingkungan tertinggi yaitu 98 dan nilai terendah yaitu 52. Berdasarkan perhitungan, diperoleh rata-rata kemampuan pemecahan masalah pencemaran lingkungan sebesar 78, simpangan baku sebesar 11,26, variansi sebesar 126,93, dan rentang 46. Nilai tertinggi berada pada rentang kelas $76-81$ yaitu sebanyak 37 responden $(29,13 \%)$. Nilai terendah berada pada rentang kelas 52-57 yaitu sebanyak 6 responden $(4,72 \%)$. Kriteria kemampuan pemecahan masalah pencemaran lingkungan sangat baik diperoleh 35 responden dengan persentase 32\%, sementara kriteria kurang baik diperoleh sebanyak 6 responden dengan persentase $3 \%$. Jika dilihat dari empat aspek kemampuan pemecahan masalah pencemaran lingkungan yang digunakan sebagai indikator, aspek yang paling banyak dikuasai oleh siswa yaitu aspek (2) merencanakan pemecahan masalah sebesar $30,19 \%$, sedangkan aspek terendah yaitu aspek (4) memeriksa kembali sebesar 18,67\%.

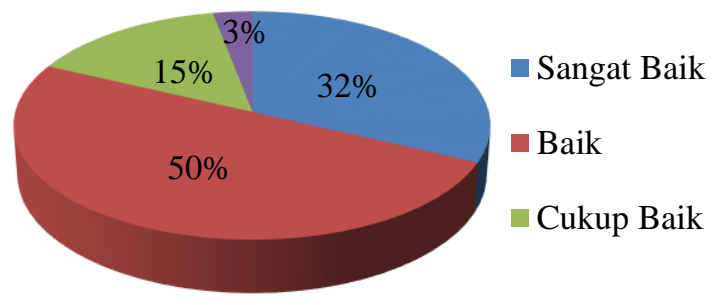

Gambar 3. Diagram lingkaran persentase jumlah siswa berdasarkan kategori penilaian kemampuan pemecahan masalah 


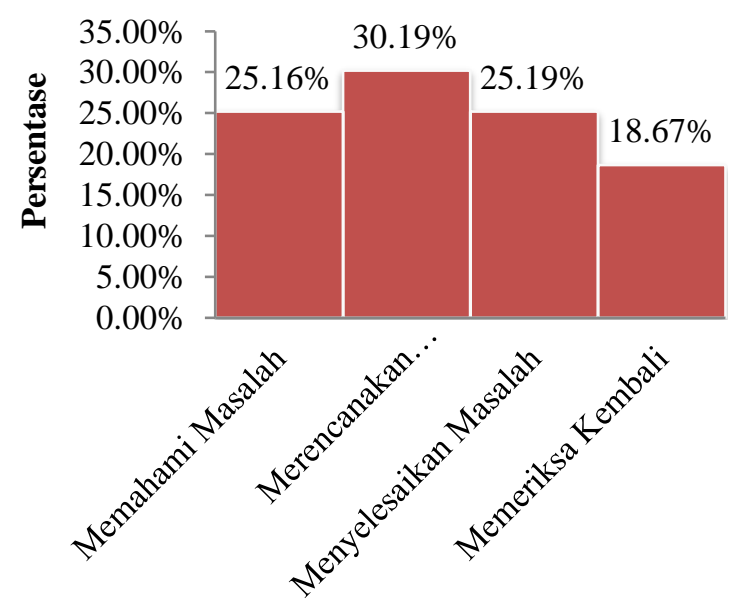

Aspek Kemampuan Pemecahan Masalah

Gambar 4. Diagram batang persentase nilai rata-rata yang dicapai siswa pada aspek kemampuan pemecahan masalah

\section{PEMBAHASAN}

Berdasarkan deskripsi data, pencapaian nilai kategori pada tes pengetahuan lingkungan hidup diperoleh persentase rata-rata berada pada kategori tinggi. Sedangkan pencapaian nilai kategori pada tes kemampuan pemecahan masalah pencemaran lingkungan siswa diperoleh persentase rata-rata berada pada kategori baik. Hal ini menunjukkan adanya siswa yang memiliki tingkat pengetahuan lingkungan hidup yang tinggi juga dapat memiliki kemampuan pemecahan masalah yang baik, sehingga pengetahuan dapat meningkatkan kemampuan pemecahan masalah siswa.

Pengetahuan tentang lingkungan hidup memiliki tiga dimensi pengetahuan yaitu dimensi pengetahuan faktual, konseptual dan prosedural. Dimensi yang paling tinggi diperoleh adalah dimensi faktual sedangkan yang terendah adalah pengetahuan prosedural. Hal ini sesuai menurut Anderson dan Krathwohl (2015) yang menyatakan bahwa pengetahuan faktual merupakan pengetahuan yang memiliki ciri elemen khusus yang dapat berupa simbol sehingga dapat dipahami lebih baik oleh siswa, sementara pengetahuan prosedural merupakan pengetahuan tentang cara melakukan sesuatu yang berupa rangkaian langkah yang harus diikuti. Sementara itu Notoatmodjo (2003) berpendapat bahwa salah satu cara untuk meningkatkan pengetahuan siswa yaitu dengan tersedianya sumber pengetahuan yang berasal dari pendidikan, buku petunjuk, pengalaman, media massa dan lingkungan.

Selanjutnya, kemampuan pemecahan masalah terdiri dari empat aspek ketercapaian indikator, yang memiliki rata-rata persentase tertinggi yaitu aspek (2) merencanakan pemecahan masalah dan terendah pada aspek (4) memeriksa kembali. Menurut Zulkhruf dan Firda (2014) dalam penelitiannya menyebutkan bahwa aspek (2) merencanakan pemecahan masalah, menyajikan secara global langkah-langkah dalam rencana pemecahan masalah dengan menggunakan informasi yang telah diketahui sebelumnya meskipun pembenaran belum diketahui. Sedangkan pada aspek (4) memeriksa kembali, membutuhkan kemampuan yang lebih untuk menemukan alternatif-alternatif solusi serta mengevaluasi jawaban yang telah diperoleh.

Berdasarkan hasil uji hipotesis, diperoleh hubungan positif antara pengetahuan lingkungan hidup dengan kemampuan pemecahan masalah pencemaran lingkungan, terbukti dari hasil penelitian diperoleh persamaan regresi yang menunjukan adanya hubungan positif. Penyebab adanya hubungan yang positif tersebut yaitu adanya keyakinan 
akan kemampuan yang dimiliki siswa untuk memecahkan masalah pencemaran lingkungan agar tercipta solusi untuk masalah lingkungan.

Siswa menggunakan kemampuan yang dimiliki untuk mengatasi masalah lingkungan dengan pengetahuan yang dimiliki. Maddux (2000) menyatakan bahwa keyakinan seseorang dalam kemampuannya untuk mencapai hasil yang diinginkan dari tindakan yang dilakukan, hal ini merupakan penentu bagi seseorang ketika memilih apakah seseorang tersebut terlibat dalam menghadapi tantangan atau sebaliknya.

Menurut Widyastutik, et. al (2014) menyatakan bahwa penyelesaian masalah yang diperoleh dalam pembelajaran merupakan penguasaan materi siswa. Penguasaan materi ini digunakan untuk mengetahui ketuntasan hasil belajar siswa. Jika kemampuan penyelesaian masalah telah diperoleh, seseorang tidak sekedar dapat menyelesaikan masalah serupa tetapi diharapkan dapat menyelesaikan masalah yang berbeda dalam kehidupan sehari-hari.

Berdasarkan hasil uji perhitungan koefisien korelasi diperoleh hasil penelitian berada dalam kategori sedang. Meskipun hasil penelitian yang telah dilakukan menunjukkan bahwa terdapat hubungan antara pengetahuan lingkungan hidup dengan kemampuan pemecahan masalah pencemaran lingkungan, dari perhitungan menghasilkan kekuatan hubungan dalam kategori sedang, namun kontribusinya termasuk kategori rendah.

Hasil ini berarti bahwa kemampuan pemecahan masalah pencemaran lingkungan siswa dalam kategori rendah ditentukan oleh pengetahuan sedangkan sisanya ditentukan oleh faktor lain. Hal ini menunjukkan bahwa dalam meningkatkan kemampuan pemecahan masalah pencemaran lingkungan yang dimiliki siswa masih banyak faktor lain yang ikut berpengaruh. Faktor tersebut dapat terjadi karena beberapa aspek, yaitu dari guru, siswa, suasana pembelajaran dan lingkungan sekolah. Nasution (2001) berpendapat bahwa penguasaan materi siswa, keterampilan belajar, sarana belajar, kondisi dari pribadi dan lingkungan belajar mempengaruhi hasil suatu pembelajaran.

Hal ini berkaitan dengan cara siswa memecahkan masalah, menurut Rofiah (2013) menyebutkan bahwa pemecahan masalah membutuhkan proses berfikir yang tidak hanya sekedar menghafal dan menyampaikan kembali informasi yang diketahui. Kemampuan juga harus menghubungkan pengetahuan serta pengalaman yang sudah dimiliki untuk berpikir secara kritis dan kreatif dalam upaya menentukan keputusan dan memecahkan masalah pada situasi baru.

Ormrod (2009) menyebutkan bahwa dalam menjawab tes pemecahan masalah, siswa harus menggunakan (yaitu mentransfer) pengetahuan dan keterampilan yang sudah ada untuk menjawab pertanyaan yang belum terjawab atau situasi yang sulit. Rofiah, et al. (2013) menyatakan bahwa kemampuan pemecahan masalah yang dimiliki oleh seseorang tidak dapat dimiliki secara langsung melainkan diperoleh melalui latihan. Hertiavi (2010) menyebutkan bahwa usaha yang dilakukan guru untuk meningkatkan kemampuan pemecahan masalah siswa adalah mengusahakan pemberian soal-soal yang berisi kemampuan pemecahan masalah dengan materi yang dipelajari.

Widyastutik, et al. (2014) menyatakan bahwa berpikir merupakan kemampuan menganalisis, mengkritisi, dan merumuskan simpulan berdasarkan inferensi dan pertimbangan yang saksama. Sehingga secara tidak langsung juga dapat melatih keterampilan penyelesaian masalah. Sementara itu, menurut Kirkley (2003) menjelaskan bahwa untuk memecahkan masalah dibutuhkan aktivitas mental yang kompleks karena tidak hanya menggunakan kemampuan berpikir dasar, tetapi juga berbagai keterampilan kognitif dan prosedur pemecahan masalah.

Berdasarkan deskripsi tersebut, maka diperlukan pengetahuan siswa tentang lingkungan untuk memecahkan masalah pencemaran lingkungan. Adanya pengetahuan 
yang dimiliki dapat menjadikan siswa berwawasan lingkungan, sehingga siswa menemukan pemecahan-pemecahan masalah yang solutif dalam pencemaran lingkungan.

\section{KESIMPULAN DAN SARAN}

Berdasarkan hasil penelitian dan pembahasan, didapatkan kesimpulan bahwa terdapat hubungan positif pengetahuan lingkungan hidup dengan kemampuan pemecahan masalah pencemaran lingkungan. Saran yang dapat digunakan untuk memperbaiki dan menyempurnakan penelitian ini yaitu, diperlukan waktu yang lebih panjang serta kerjasama yang baik antara guru dengan siswa, perlu adanya model pembelajaran dan suasana pembelajaran yang mendukung, dan perlu diadakan penelitian lebih lanjut dengan menambahkan variabel lain.

\section{DAFTAR PUSTAKA}

Anderson, L. W \& Krathwohl, D.R. (2015). Kerangka Landasan untuk Pembelajaran, Pengajaran, dan Asesmen (Revisi Taksonomi Pendidikan Bloom). Yogyakarta: Pustaka Pelajar.

Badan Lingkungan Hidup Kota Tangerang. (2015). Laporan Status Lingkungan Hidup Kota Tangerang Tahun 2014. Tangerang: Pemerintah Kota Tangerang Provinsi Banten.

Hertiavi, et al. (2010). Penerapan Model Pembelajaran Kooperatif Tipe Jigsaw untuk Peningkatan Kemampuan Pemecahan Masalah Siswa SMP. Jurnal Pendidikan Fisika, 6, 53-57.

Kirkley, J. (2003). Principles for Teaching Problem Solving: Technical Paper. Indian University: Plato Learning.

Maddux, J. E. (2002). Self-efficacy. In C. R. Snyder \& Lopez (Eds), Handbook of Positive Psychology. New York: Oxford University Press.

Nasution, H. M. F. (2001). Hubungan Metode Mengajar Dosen, Keterampilan Belajar, Sarana Belajar dan Lingkungan Belajar dengan Prestasi Belajar Mahasiswa. Jurnal Ilmu Pendidikan, 8(1), 38-46.

Notoatmodjo, S. (2003). Pendidikan dan Perilaku Kesehatan. Jakarta: Rineka Cipta.

Ormrod, J. E. (2009). Education Psychology, Developing Learners. Ohio: Carlisle Communication, Ltd.

Rofiah, E, et al. (2013). Penyusunan Instrumen Tes Kemampuan Berfikir Tingkat Tinggi Fisika pada Siswa SMP. Jurnal Pendidikan Fisika, 1, 17-22.

Sastrawijaya, T. (2009). Pencemaran Lingkungan. Jakarta: Rineka Cipta.

Sugiyono. (2014). Metode Penelitian Kuantitatif Kualitatif dan R\&D. Bandung: Alfabeta.

Widyastutik, I, et al (2014). Penerapan Model Problem Based Instruction (PBI) pada Tema Pencemaran Air untuk melatih Keterampilan Menyelesaikan Masalah. Jurnal Pendidikan Sains e-Pense, 2(1), 1-7.

Zukhruf, R \& Nurrakhmi, F. (2014). Profil Intuisi Siswa SMA dalam Memecahkan Masalah Turunan Ditinjau dari Gaya Kognitif Field Dependent dan Field Independent. Jurnal Ilmiah Pendidikan Matematika, 3, 208-214. 